\title{
DETECTING MEAT FRAUD IN FOOD SUPPLY CHAIN
}

\section{Radmila Crceva Nikolovska ${ }^{1}$, Aleksandra Angeleska ${ }^{2}$, Aleksandar Nikolovski ${ }^{3}$, Elizabeta Stojkovic Dimitrievska ${ }^{4}$, Vasilka Poposka Treneska $^{5}$, Blagica Sekovska ${ }^{6}$}

\begin{abstract}
In recent years, numerous reports have repeatedly highlighted a series of food safety scandals involving contaminated and forged meat and fish products, grains and fruit products, juices, cooking oils, and spices and herbs, distilled beverages and pet treats. Foods that have been found to be stained with chemicals, illicit drug residues, additives and dyes, pathogenic microorganisms and other pests. Some foods enter the market have expired well or are unhygienic.

Economic gain is the goal of food fraud. Food fraud and the prevention of such fraud are very important processes in the food industry. Such frauds are economically motivated, rated as criminal behaviour, and the moment we understand criminal behaviour and decision making we will be able to calculate and exclude the risk of food fraud. By analysing financially motivated fraud that combine opportunities, motivations, and inadequate control measures, we can assess the likelihood of fraud
\end{abstract}

1 Radmila Crceva Nikolovska, Ph.D., Scientific Associate, Department of Animal Nutrition, Faculty of Veterinary Medicine, University "St. Cyril and Methodius", Lazar Pop Trajkov Street no. 5-7, 1000 Skopje, Republic of North Macedonia, Phone: +389 70262 282, E-mail: rnikolovska@,fvm.ukim.edu.mk

2 Aleksandra Angeleska, Ph.D., Faculty of Veterinary Medicine, University "St. Cyril and Methodius", Lazar Pop Trajkov Street no. 5-7, 1000 Skopje, Republic of North Macedonia, Phone: +389 23240 716, E-mail: mizasandra@yahoo.com

3 Aleksandar Nikolovski, DVM, Ontario Ministry of Agriculture, Food and Rural Affairs, Dumbarton Street no. 115, N1E3T5, Guelph, Ontario, Canada, Phone: +416 93182 69, E-mail: nikolovski.aleksandar@gmail.com

4 Elizabeta Stojkovic Dimitrievska, Ph.D., Scientific Associate, Faculty of Veterinary Medicine, University "St. Cyril and Methodius", Lazar Pop Trajkov Street no. 5-7, 1000 Skopje, Republic of North Macedonia, Phone: +389 23240 748, E-mail: edimitrieska@fvm.ukim.edu.mk

5 Vasilka Popovska Trenevska, Ph.D., Associated Professor, Department of Statistics, Faculty of Veterinary Medicine, University St. Cyril and Methodius, Lazar Pop Trajkov Street no. 5-7, 1000 Skopje, Republic of North Macedonia, Phone: +389 23240 748, E-mail: vasilka@fvm.ukim.edu.mk

6 Blagica Sekovska, Ph.D., Full Professor, Department of Rural Economy and Management, Faculty of Veterinary Medicine, University St. Cyril and Methodius, Lazar Pop Trajkov Street no. 5-7, 1000 Skopje, Republic of North Macedonia, Phone: +389 70708730 , E-mail: bsekovska@fvm.ukim.edu.mk 
in any food product or component. The modified ingredients are specially designed to avoid quality assurance and quality control systems for customers. Only people who manipulate the ingredients know what substances and how to manipulate them. In addition, fraudulent ingredients are often unconventional substances that do not meet the requirements of food safety management systems, and become known only after they are incorporated into the supply chain.

International standards for food and regulations address the risk of fraud food adulteration. European Union (EU) Directives, Global Food Safety Initiative (GFSI) Codex Alimentarius has continued work on a food fraud, or how, food fraud fits into their benchmarking.

The problem of detection and typing of meat in meat products in the world and lack of research on them in the Republic of North Macedonia was the main goal for this paper.

Our task was identification of meat type by ELISA method and proof of counterfeiting of meat products. Analyses are made in the laboratories of the Institute of Food at the Faculty of veterinary medicine in Skopje

A total of 350 samples of various heat-treated meat products subgroups of meat sausages in pieces were examined for detection, typifying and quantifying the type of meat used for production.

Key words: meat, meat products, fraud, ELISA test.

JEL'? Q13, Q17, Q18

\section{Introduction}

Over the years, world has introduced a number of bills intended to address concerns about food fraud for a food or food ingredient. The world has stressed the need to step up measures to prevent food fraud after several scandals. Food fraud, whether committed by producers, retailers or importers, endangers the entire food industry, and provides enormous economic benefits to executives. Today's food safety and quality management systems enable fraud prevention. All of these measures aim to provide safe food for consumers. Worldwide food scams make about 40 billion of USD every year. Only one incident can permanently destroy a well-known brand, shut down exports, and completely lose public trust (EIU, 2012).

Quality systems are generally designed to control known food ingredients that may inadvertently contaminate food as pathogenic microorganisms or preparations. Food

7 Article info: Review Article, Received: $27^{\text {th }}$ September 2019., Accepted: $7^{\text {th }}$ November 2019. 
scams are done to provide economic benefits. Most often, criminals who commit food fraud cannot determine whether their activity will result in a safety or risk of toxins to the consumer. Consequently, consumers are at high risk of a health threat posed by dangerous products (COSO, 2012).

Each food product depends on its composition, quality, production process, supply chain and geographical origin determines the likelihood of fraud. It is always easier to chew on liquids than solid foods, as well as complex foods made from several ingredients are easier to cheat. Long supply chains result in a higher risk of food fraud. Buyers are dependent on food vendors to present the truth about food information. The biggest scams occur when wholesale is traded globally, especially primary agricultural products coming from households, end users, through retailers, suppliers and retailers (Gasiorowski, 2006; COSO, 2012).

Increasing revenue and minimizing costs are the two forms of basic economic motivation for food fraud. It is always the market conditions that dictate which product to counterfeit. The more the market is interested in that product, the more cost-effective it is to counterfeit that product with cheaper ingredients. High-priced food or products with significant price differences are the most profitable and offer the greatest opportunity for fraudsters. The economic motivation for fraud will be less when the seller and the buyer have a long-term relationship and a history of conducting mutually beneficial transactions. That's why counterfeit products are often counterfeit rather than lesser known, so the payoff is much lower (Wolfe, Hermanson, 2004; CRS, 2014).

Any company that wants to ensure a quality product does not deceive the ingredients used in the final product manufacturing process must take action through quality systems, food safety management and staff at all levels. External controls are implemented by food safety agencies, regulations and laws. The importance of protecting against food fraud and of employees, suppliers and customers is of great importance (ACFE, 2016).

All that we have said on previous pages indicates that food scams are becoming more common and causing widespread public concern. All the scandals so far worldwide have increased the need to protect consumers at all levels from ingredient selection to final product throughout the entire supply chain. The risks have never been higher (Spink, Moyer, 2011).

Meat is one of the food items that always make it to the list of most falsified food in the world. While the true extent of fraud isn't clear to us, the picture is looking grim: in 2015, 483 million USD worth of smuggled meat was seized by Chinese authorities. Some of this meat were repeatedly frozen and thawed meat dating back to the 1970s and were meant to be sold to consumers at the time it was seized (GAO, 2011). 


\section{Methodology and Case Results}

The problem of detection and typing of animal protein in food especially meat product in the world and lack of research on them in the Republic of North Macedonia was the main goal for this paper.

Our task was identification of meat type by ELISA method and proof of counterfeiting of meat products. Analyses are made in the laboratories of the Institute of Food at the Faculty of veterinary medicine in Skopje.

A total of 350 samples of various heat-treated meat products subgroups of meat sausages in pieces were examined for detection, typifying and quantifying the type of meat used for production (OGRM, 2013).

\section{Food Fraud Types, Definitions and Examples}

Certain food fraud types, definitions and examples could be seen throughout the next table (Table 1.).

Table 1. Food fraud types, definitions and examples

\begin{tabular}{|l|l|l|}
\hline \multicolumn{1}{|c|}{ Term } & \multicolumn{1}{|c|}{ Definition } & \multicolumn{1}{c|}{ Example } \\
\hline Adulteration & $\begin{array}{l}\text { Ingredient of the finished product is } \\
\text { fraudulent }\end{array}$ & Melamine add to milk \\
\hline Tampering & $\begin{array}{l}\text { To render something harmful or } \\
\text { dangerous by altering its structure }\end{array}$ & $\begin{array}{l}\text { Changed expiry date, product up- } \\
\text { labelling, religious designation. }\end{array}$ \\
\hline Simulation & $\begin{array}{l}\text { Product is designed to look like } \\
\text { but not exactly copy the legitimate } \\
\text { product }\end{array}$ & $\begin{array}{l}\text { "Knock-offs" security systems chang- } \\
\text { es. }\end{array}$ \\
\hline Counterfeiting & $\begin{array}{l}\text { Made in imitation of something } \\
\text { else with intent to deceive }\end{array}$ & $\begin{array}{l}\text { Copies of a well-known brand of food } \\
\text { made with other security systems. }\end{array}$ \\
\hline
\end{tabular}

Source: Spink, Moyer, 2011.

\section{Review of Incidents}

In order to understand the seriousness of meat fraud in paper is presented some of the biggest meat fraud scandals that hit recent times (CRS, 2014).

\section{Horsemeat Scandal}

The "Horsemeat Scandal of 2013" was the incident that led to UK/DEFRA. The discovery that frozen burger patties sold around Europe contained horse DNA which led to the floodgates being opened to a larger, more harrowing truth: horse meat was, in fact, being used in some processed beef products. 
The scale was big. Horse meat was initially found in frozen beef burgers made in the UK and Ireland, which are then sold in UK supermarket. Following the scandal, raids and arrests have been made in the UK, France and Denmark. The Republic of Ireland and Northern Ireland were asked to consider whether the inclusion of horsemeat in beef products was accidental or whether it was deliberate. The Food Standard Agency (FSA) also reacted to the scandal by launching a three-phase, UK-wide survey of food authenticity to test 514 products to check beef and other meat products (COSO, 2012).

\section{China Fake Meat Scandal}

It seems 2013 wasn't a very good year for meat: in China, over 900 arrests were made following authorities seizing 20,000 tons of illegal meat, solving 382 cases of meatrelated crime over a span of three months. In one of the cases, it was discovered that a gang was passing off fox, mink and rat meat as mutton. The fake meat was said to be treated with gelatine, carmine, a colour produced using ground beetles, and nitrate, and then sold as mutton in farmers' markets in Jiangsu province and Shanghai. The gang in question made over $£ 1 \mathrm{~m}$ in a span of four years by falsifying mutton this way.

In another case, suspects in Baotou city used duck meat to sell fake beef and lamb jerky to 15 provinces. The falsification was discovered after a test showed elevated levels of E. coli in the meat that "seriously exceeded standards".

China's meat market is notorious for various food safety scares including avian flu, disease-ridden meat and falsification such as the cases described above. The Fake Meat Scandal of 2013 didn't help its reputation, but it did lead to Chinese authorities announcing new guidelines for harsher penalties for anyone found falsifying food products as a result of the scandal (CRS, 2014).

\section{Operation Weak Flesh}

Brazil's 14 billion USD meat export industry was hit by a major scandal with Operation Weak Flesh, a two-year police investigation into alleged bribery of over 100 food sanitation inspectors by the world's biggest poultry exporter, BRF SA, and top beef producer JBS. It was discovered that the bribed inspectors allowed the sale of rancid products, falsified inspection documents or failed to inspect the meatpacking plants at all (ACFE, 2016).

You will notice common factors about the reports on these meat fraud scandals: all of them note gaps in legislation and food safety guidelines; all of them note vulnerabilities in the food production chain; and all of them are cases where proper tracking of sources and conditions could've prevented the fraud from happening. Even with food regulatory authorities worldwide and the World Health Organization taking steps to 
improve food safety, the call for a secure and reliable system to track the food supply chain is imperative now more than ever before.

\section{Situation in North Macedonia}

A total of 350 samples of various heat-treated meat products subgroups of meat sausages in pieces were examined for detection, typifying and quantifying the type of meat used for production (OGRM, 2013).

Mentioned could be seen in next table (Table 2.).

Table 2. Various heat-treated meat products

\begin{tabular}{|c|c|c|c|}
\hline \multicolumn{4}{|c|}{ Meat products } \\
\hline Category & Group & Subgroup & Products \\
\hline \multirow{3}{*}{ Sausage } & \multirow{3}{*}{$\begin{array}{l}\text { Heat treated } \\
\text { sausages }\end{array}$} & Rainy & $\begin{array}{l}\text { Hotdog }^{1} \\
\text { Sausage }^{2} \\
\end{array}$ \\
\hline & & Meat sausage in pieces & $\begin{array}{l}\text { Ham in the hose } \\
\text { Pariser }^{4}\end{array}$ \\
\hline & & Durable sausages & Succulent $^{5}$ \\
\hline \multicolumn{4}{|c|}{ Poultry meat products } \\
\hline Sausage & $\begin{array}{l}\text { Semi-durable } \\
\text { sausage }\end{array}$ & & Chicken breasts ${ }^{6}$ \\
\hline
\end{tabular}

Source: Crceva Nikolovska, 2015.

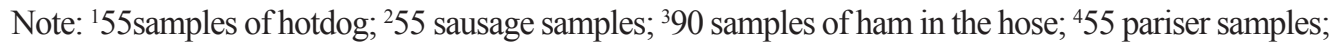
${ }^{5} 45$ samples of succulent; ${ }^{6} 50$ samples of chicken breasts.

All examined samples are taken from production plants in the territory of the Republic of North Macedonia, in the period of 2017 to 2018. Samples were delivered in original packaging.

We identified them with ELISA-TEKTM Cooked Meat Speciation Kits the types of meat used in the production of meat preparations through simple extraction and double sandwich ELISA.

In this type of ELISA, antibodies are located in the wells on microtiter plates. When the specimens are applied to them if in, they have a tissue antigen of the examined strain that binds to the antibodies that are found in wells and form an antigen/ antibody complex.

The results we obtained when analysing meat products, with the aim of detecting, typing and quantifying the type of meat used in their production. The first analysis we did to identify the type of meat in the marketed meat products showed that from the analysed 350 samples of different kinds of meat products and different producers in 120 samples or $34 \%$ of all types of meat products we identified a type 
of meat that was not declared on the product. The results of the analysis of the meat products by species showed that 20 out of 55 hotdogs (36.4\%), 23 out of 55 parisers (42\%), 47 out of 90 ham in the hose (52\%), 7 out of 45 succulent $(15.5 \%), 10$ out of 50 chicken breasts $(20 \%)$ and 13 out of 55 sausages $(23.6 \%)$ do not correspond to the declared (Table 2). $34 \%$ of them do not contain only the declared type of meat but have the presence of at least one type of meat. The counterfeiting was usually done by adding pork and chicken due to the large price difference. Confirmation by real-time PCR method has been carried out for specimens found to contain pork not specified in the declaration.

Based on the results of this study counterfeiting meat products is present in meat industries in Macedonia, it is common to substitute quality meat with less quality. Protecting consumers and avoiding unfair competition requires tighter food control and institutions must continually control meat and meat products using effective methods (Crceva Nikolovska, 2015).

\section{Discussion}

The analytical methods used to identify meat of different species in meat products are based on the peptides and proteins present in the product. Each species has unique proteins used as markers and their specific peptides are targeted to them in the assays (Giovannacci et al., 2004). Cross-reactions are not obtained when using these methods and if the product contains milk, soy or egg white (Patterson, Spencer, 1985). By such methods, although there are more ingredients in the product such as hotdogs, it is clear that in addition to chicken and veal, undeclared pork is often added (Bonwick, Smith, 2004). One study in the UK found that less than half of the samples examined showed the presence of DNA that was not declared on the packaging. From a total of 665 samples analysed in 2017 from England, Wales and Northern Ireland, the Food Standards Agency (FSA) found that 145 declarations were partially or completely made up of unspecified meat. Samples were taken from 487 businesses, from restaurants to supermarkets. Seventy-three of the contaminated samples came from retailers, including three supermarkets. Fifty samples were from restaurants, while the remaining 22 came from processing plants. The results showed that some samples did not contain traces of meat on the product label, while others contained DNA from multiple animals, even four in some cases. Beef DNA was the most commonly found contaminant, followed by pigs, chicken, sheep and turkey in that order. Minced meat was the most commonly misidentified product, while sausages, kebabs and fishermen from restaurants were also among the best offenders (Spink, Moyer, 2011; Spink et al., 2013). 
Managing the dangers of food fraud has led to regulatory requirements around the world, reducing the proportion of fraud and establishing control mechanisms. The most responsible in the entire food industry are companies and their leaders, which require a very active and proactive approach to tackling food fraud. Companies that are part of the food industry regardless of any current or future regulatory requirements for compliance are the ones that can reduce the likelihood of fraud. Increasing awareness of food fraud has also encouraged the academic community to become more involved in the prevention of food fraud. Because of the health hazards and extensive economic losses, science has focused on discovering methods that can detect fraud, which will be a key activity to reduce fraud, detection and prevention (Ayaz et al., 2006; Crceva Nikolovska, 2015).

\section{Conclusion}

With the increasing number of fraudulent products, in order to prevent this occurrence, a wide range of scientific techniques for the protection of consumers and especially small traditional food producers need to be developed. Continued efforts to address food quality issues can be achieved through proven methods that can routinely respond to requests. Authorities should ensure continuous monitoring with improved and expanded scope of methods across the food industry.

\section{References}

1. EIU (2012). Global Food Security Index 2012. Economist Intelligence Unit (EIU) Limited, London, UK.

2. GAO (2011). High-Risk Series: An Update. In: Report to Congressional Committees, GAO-11-278, February 2011, US Government Accountability Office (GAO), Food and Drug Administration, Washington, USA, available at: www.gao.gov/new.items/d11278.pdf

3. CRS (2014). Food Fraud and Economically Motivated Adulteration of Food and Food Ingredients. United States Congressional Research Service (CRS), Washington, USA, available at: https://fas.org/sgp/crs/misc/R43358.pdf

4. COSO (2012). Risk Assessment in Practice: Enterprise Risk Management. Committee of Sponsoring Organizations of the Treadway Commission (COSO), Durham, USA.

5. ACFE (2016). The Fraud Triangle. Association of Certified Fraud Examiners (ACFE), Austin, USA, available at: www.acfe.com/fraud-triangle.aspx

6. Wolfe, D. T., Hermanson, D. R. (2004). The Fraud Diamond: Considering the Four Elements of Fraud. CPA Journal, 74(12):38-42. 
7. Spink, J., Moyer, D., Park, H., Heinonen, J. (2013). Defining the Types of Counterfeiting, Counterfeiters, and Offender Organizations. Crime Science, 2(8):1-9.

8. Spink, J., Moyer, D. C. (2011). Defining the Public Health Threat of Food Fraud. Journal of Food Science, 76(9):R157-R163.

9. Gasiorowski, M. (2006). Ochrona produktow tradycyjnych i regionalnych. Produkt tradycyjny i regionalny. Agro-Smak, Fundacja Fundusz Wspolpracy, 9(2):4-7.

10.Crceva Nikolovska, R. (2015). Типизација на анимални протеини во храна $u$ добиточна храна $u$ компарација хна различни медоти за нивна детекција. Doctoral dissertation, Faculty of Veterinary Medicine, University St. Cyril and Methodius, Skopje, Republic of North Macedonia.

11.OGRM (2013). Rulebook on Requirements for Quality of Mines Meat, Meat Preparations and Meat Products. Official Gazette of the Republic of Macedonia, no. 63/2013.

12.Patterson, R. M., Spencer, T. L. (1985). Differentiation of Raw Meat from Phylogenically Related Species by Enzyme-Linked Immunosorbent Assay. Meat Science, 15(3):119-123.

13.Bonwick, G. A., Smith, C. J. (2004). Immunoassays: Their History, Development and Current Place in Food Science and Technology. International Journal of Food Science \& Technology, 39(8):817-827.

14.Giovannacci, I., Guizard, C., Carlier, M., Duval, V., Martin, J. L., Demeulemester, C. (2004). Species Identification of Meat Products by ELISA. International Journal of Food Science \& Technology, 39(8):863-867.

15.Ayaz, Y., Ayaz, N. D., Erol, I. (2006). Detection of Species in Meat and Meat Products Using Enzyme-Linked Immunosorbent Assay. Journal of Muscle Foods, 17(2):214-220. 